\section{THE STORY OF JADE}

\section{Adventure in Jade}

By James Lewis Kraft. Pp. ix +81. (New York : Henry Holt and Co., 1947.) 3.50 dollars.

TADE was used for ornaments and tools by the $\int$ native peoples of Mexico, Central America and Peru, by the Indians of British Columbia, and by the Eskimos. The source of the jade was something of a mystery. In the absence of any known sourceseither of nephrite or jadeite- on the American continent, it was supposed, up to ten or twenty years ago, that the jade used by the Eskimos and also that of the Maya and other Central and South American peoples had been brought in from Asia. Of late years, however, some localities for jade have been found in the United States, and Mr. J. Lewis Kraft tells the story of these discoveries.

The subject of the book is of particular interest to Americans not only because of this problem of the origin of the ancient worked articles of jade, but also because there has grown up in the United States a widespread and very active interest in all kinds of semi-precious stones. All over the country there are now local societies and clubs the common interest of which is the search for semi-precious stones and the fashioning of these stones into cabochons and faceted stones for collection specimens or jewellery. Many amateur lapidaries have acquired great skill at this work, and Mr. Kraft is one of these.

His book is not deeply scientific. It is the story, simply told, of how a very busy man found an absorbing interest in jade and the fashioning of it with his own hands into pieces for his collection, presents for his friends, and jade rings as awards for merit to his "fellow workers at the Company". There is much of legend and folk-lore in the book and tales of miners and prospectors and their finds. The author has encouraged or persuaded several prospectors to search for jade, giving them fresh clues to follow or urging them to penetrate to such remote regions as Jade Mountain in Alaska, discovered by George M. Stoney so far back as 1886 but scarcely ever visited since. In Wyoming, nephrite was found near Lander in 1931, and two other occurrences in that State are recorded in this book. An immense boulder weighing 2,490 lb. from Crooks Mountain, fifty miles south-west of Lander, was removed under the author's supervision, transported to Chicago and presented to the Natural History Museum there in 1944.

Ten years ago Pabst's "Minerals of California" contained no record of jade; now the author describes four localities in Califormia from which he has obtained good nephrite. The story of one of these finds reads like the discovery of the first diamond in South Africa. In 1880 a hunter after sea lion entered a cave on the coast of Monterey County. Finding the cave-floor covered with shining green pebbles, he took some home. Fifty or sixty years later a visitor to the hunter's home noticed the children, grandchildren of the hunter, playing with the pebbles. Being interested, he took some back to Stanford University. They were identified as nephrite, and afterwards an enterprising search resulted in the rediscovery of the cave and the recovery of some of the nephrite pebbles and boulders which strew its floor.

It seems that at all these Californian localities the jade is nephrite, so the source of the jade used by the Mexicans, which is largely jadeite, is still to be found. One feels sure that Mr. Kraft will leave no stone unturned until he solves this problem too.

Special care has been taken in the design and type for this book, and the result is a fine example of modern printing. All the royalties will go into a charitable trust.

\section{PHYSICAL PLANNING IN THE SOUTH-WEST OF ENGLAND}

\section{Devon and Cornwall}

A Preliminary Survey. A Report issued by the Survey Committee of the University College of the South-West, Exeter. Pp. iv +318. (Exeter : A. Wheaton and Co., Ltd., 1947.) 31s. 6d. net.

TN the provisions of the Town and Country Planning Act, 1947, Britain is committed to the planning of the use of every acre of its land surface, and the county authorities become the primary planning authorities. They are required to put forward their proposals for the approval of the Minister within a brief space of time, and there is a very real danger that far-reaching decisions on policy will be taken with a totally inadequate foundation of factual knowledge. It is therefore of the utmost importance that surveys such as this volume on Devon and Cornwall should be undertaken and made available at the earliest possible opportunity. There is an obvious advantage in such work being undertaken by independent groups with no preconceived points of viow and with no axe of their own to grind.

Like the survey of Herefordshire previously issued by the West Midland Group, this survey of the south-west has been undertaken by a representative survey committee, headed by the principal of the University College of the South-West, Exeter, and including both members of the College and experts from outside. The result is a comprehensive account, well documented, adequately provided with statistical information and with a number of excellent maps and diagrams covering the two counties. Published or other documentary material has been supplemented from the results of field surveys, notably one carried out by groups from the College in 1944. Particularly instructive are the attempts to show on a cartographical basis the spheres of influence of the urban centres in these two rural counties. In places the point of view is that of the townsman visiting the country rather than that of the dweller in the village, and it would be possible to criticize in detail some of the maps, as well as some of the information, particularly regarding that rather remote area of north-east Cornwall and adjoining parts of Devon, where the text and maps suggest a stagnation of social life rather far from the experience of those who know the area intimately from within.

There is no indication as to the authorship of the individual sections, and one wonders whether the general conclusions of the excellent first section on population are those of the whole group or of the individual responsible, especially when one reads, "The whole emphasis should be on providing the country with the amenities of the town". Further, the separate contributions tend to be distinct essays rather than a connected whole. Whereas some summarize published information, others contain 